\title{
Present Strategies for Critical Bone Defects Regeneration
}

\author{
Mouetaz Kheirallah $^{1^{*}}$ and Hassan Almeshaly ${ }^{2}$ \\ ${ }^{1}$ Maxillofacial Surgery, Department, College of Dentistry, Alanadalos University for Medical Sciences, Al-Qadmous, Syria \\ ${ }^{2}$ Dental Sciences, College of Dental Medicine, Majmaah University, Kingdom of Saudi Arabia
}

*Corresponding author: Mouetaz Kheirallah Maxillofacial Surgery Department, College of Dentistry, Alanadalos University for Medical Sciences, Al-Qadmous, Syria, Tel: 96343657600; E-mail: moutazkheirallah@gmail.com

Rec date: Oct 22, 2016; Acc date: Nov 26, 2016; Pub date: Dec 01, 2016

Copyright: (c) 2016 Kheirallah M, et al. This is an open-access article distributed under the terms of the creative commons attribution license, which permits unrestricted use, distribution, and reproduction in any medium, provided the original author and source are credited.

\begin{abstract}
A critical size bone defect may arise due to severe trauma or tumors where a large portion of the bone is removed. In some instances, autografts cannot be used for filling such large defects. Allografts may be used to reconstruct large bone defects, but these grafts may not incorporate in the healing response. Consequently, it is still a challenge for reconstructive surgery to reconstruct large bone defects. A variety of treatment strategies have been progressed to promote the healing response and close the bone defects. Micro and nano particles (MNPs) technology is a newer option than traditional grafts, which may defeat many limitations of the bone graft usage. However, there are still no well approved treatment strategies to override all the expected requirements. Due to the existence of variety strategies for treatment of critical size bone defects, this impartial review, highlights on the techniques and strategies that have been accomplished to anatomize the complicated treatment problems of large bone defect healing, the limitations of therapeutic relevant biodegradable materials, and service the regeneration of large bone defects.
\end{abstract}

keywords: Scaffolds; Composite materials; Critical bone defects; Bone healing; Nanomaterials; Neovascularization

\section{Abbreviations \\ MNPs: Micro/Nano Particles; TGF- $\beta$ : Transforming Growth Factor- $\beta$; BMPs: Bone Morphogenic Proteins; DBM: Demineralized Bone Matrix; HA: Hydroxyapatite; $\beta$ TCP: $\beta$ Tricalcium Phosphate; PTH: Parathyroid Hormone; PLAGA: Poly Lactic-co-Glycolic Acid; PEVA: Poly(Ethylene-Vinyl Acetate); ADMSCs: Adipose-Derived Mesenchymal Stem Cells; VEGF: Vascular Endothelial Growth Factor; PLGA/HA/SIM: Poly(Lactic-co-Glycolic Acid)/Hydroxyapatite/ Simvastatin; PLLACL: Poly(L-Lactide-Co-Caprolactone)}

\section{Introduction}

A critical size bone defect is a large void in a bone whereby the bone cannot heal itself naturally [1]. This may arise due to severe trauma or tumors where a large portion of the bone is removed, or it may occur due to bone irradiation. The critical size defect appears to be equal to or greater than $20 \%$ of the length of a long bone [2]. Bone defect healing passes in several phases, these include hematoma formation, inflammation, soft cartilaginous callus formation, neovascularization, soft callus mineralization, hard callus formation and osteoclastic remodeling of the hard callus to create the lamellar bone [3]. Bone healing is not sufficient in large bone defects and may be complicated. Under these circumstances, the autografts are the most popular method for bone replacement [4-6]. In some instances, autografts cannot be used for filling such large defects. Allografts may be used to reconstruct large bone defects, but these grafts may not incorporate in the healing response; hence, it may be absorbed by the rejection. Xenografts are more popular than auto and allografts, but the healing process outcomes are poorly understood [7]. Also, considering the large number of local complications and the unpredictable nature of the radiological and histological outcome xenografting should be discontinued [8]. Consequently, it is still a challenge for reconstructive surgery to reconstruct large bone defects. A variety of treatment strategies have been progressed to promote the healing response and close the bone defects. Micro and Nano particles (MNPs) technology is a newer option than traditional grafts, which may defeat many limitations of the bone graft usage. However, there are still no well approved treatment strategies to override all the expected requirements. Simvastatin seems to play an important role in bone regeneration by participating in osteoblast activation (increasing BMP2 expression) and in osteoclast inhibition, also by stimulating neovascularization [9]. Local delivery of simvastatin from carriers appears to be an attractive solution to the problem of maintaining therapeutic doses to treat large bone defects and to minimize undesired side effects [10]. Generally, controlled release of drugs can be triggered by various external or internal stimuli. The idiom "smart" has been applied to MNPs that can react in an expectant and certain course to external and internal stimuli. Light, ultrasound, electromagnetic fields, and temperature, are known as external stimuli, while $\mathrm{pH}$, redox, enzyme activity and temperature, are internal stimuli $[11,12]$. Thus, controlled drug delivery approaches based on micro/ nano particles could be a promising approach for sustained-localized delivery of simvastatin. Due to the existence of variety strategies for treatment of critical size bone defects, this impartial review, highlights on the techniques and strategies that have been accomplished to anatomize the complicated treatment problems of large bone defect healing, the limitations of therapeutic relevant biodegradable materials, and service the regeneration of large bone defects.

\section{Bone Defects Healing}

Bone tissue consists of bone extracellular matrix and bone cells, extracellular matrix is comprised of both organic and inorganic components [13]. The organic components are formed of type-I 
collagen fibrils, osteopontin and osteocalcin. Within the bone extracellular matrix, osteopontin is known to promote cell attachment through covalent binding with fibronectin and type I collagen. Both osteopontin and osteocalcin have an alliance with calcium and may support the nucleation of calcium phosphate during mineralization [14]. The inorganic components of the matrix are calcium, carbonate, and phosphate ions, arranged in a crystalline-like structure. Matrix mineralization starts with nucleation of calcium phosphate crystals, and followed by crystal growth [15]. Non-collagenous proteins can be nucleation points for crystallization [16]. There are three types of bone cells in bone tissue: osteoblasts, osteoclasts, and osteocytes. Osteoblasts are responsible for bone formation through the synthesis and secretion of an organic extracellular matrix, also synthesize a variety of growth factors including transforming growth factor- $\beta$ (TGF- $\beta$ ) and bone morphogenic proteins (BMPs) that can aid in both the recruitment and differentiation of stem cells. When matrix is no longer actively being formed, the osteoblasts become embedded within the extracellular matrix and become osteocytes. Osteoclasts are responsible for bone resorption. Communication between the three types of bone cells regulate the formation and resorption of bone [10].

\section{Enhancement and Limitations of Bone Defects Healing}

Four elements are needed for bone grafts healing, osteoconduction, osteoinduction, osteointegration, and osteogenesis. Osteoconduction is the ability to support bone growth on a surgical site, during which pores, channels, and blood-vessels are formed within the bone. Osteoblasts from the margin of the defect that is being grafted utilize the bone graft material as a framework upon which to spread and generate new bone. Osteoinduction involves the stimulation of osteoprogenitor cells to differentiate into osteoblasts that then begin new bone formation. Osteointegration is the direct contact of living bone to graft material. Finally, osteogenesis is the formation of new bone by osteoblasts within the graft material [17]. It is important to link these elements together by assessing all techniques, materials and information available for bone regeneration. Different treatment strategies have been designed to increase the effectiveness, rate and quality of bone defect healing. Each modality has its own limitations, therefore has not been suggested as a perfect modality to enhance the healing of bone defects. One of the alternative clinical techniques is Masquelet technique. This technique is divided into two stages, during 1 st stage, biological membrane is applied on a cement spacer, this acts as chamber for insertion of non-vascularized autograft at the 2nd stage [18]. Another technique used to enhance bone defects regeneration is the distraction using intramedullary devices [19]. However, this technique needs long time ( $1 \mathrm{~mm}$ per day) and may be associated with complications [20]. Autografts provide necessary components dependent on each other to promote bone regeneration. Autograft contains collagen and bone minerals so it forms, a scaffold for osteoconduction, also, it includes non-collagenous bone matrix proteins which regulate activities of bone cells for osteoinduction, and it takes in progenitor cells for osteogenesis [5,21]. Autograft can be harvested as a tricortical graft for structural support [22], or as a vascularized bone graft for restoration of large bone defects [23]. The anterior and posterior iliac crests are the commonly used donor sites. Nevertheless, harvesting requires an additional surgical procedure [24-26]. Although, autografts do not stimulate immune response, and can integrate into their new site, they are associated with morbidity, infection, and pain at the donor site. Allografts are available in many combinations, such as demineralized bone matrix (DBM), morcellised cancellous chips, cortico-cancellous and cortical grafts. All lack cellular component and osteoinductive properties because they are devitalized by irradiation or freeze-drying processes [27]. Allografts and xenografts are straightforward obtainable, but they have lazy incorporation and likely graft rejection. Furthermore, freezing or freeze drying; may modify the basic characteristics and architecture of the grafts $[28,29]$. Moreover, the most evident limitation of allograft is its deficiency of osteoinductive ability. For example, demineralized bone matrix (DBM) is prepared by trituration of allogenic, followed by mild acid extraction of the mineralized phase of bone. This process results in a composite of non-collagenous proteins, growth factors, and collagen [30]. Decellularized extracellular matrices (ECM) from other mammalian tissues have been used also as biological scaffolds for bone regeneration [31-33]. DBM is osteoconductive but does not extend structural support. When preparing demineralized bone matrix for implantation in the defect site, it is usually used as bone graft pasta and mixed with bone marrow, to increase osteogenic factors [34]. Bone graft substitutes consist of scaffolds made of natural or synthetic biomaterials that promote bone healing. There are broad range of synthetic bone substitutes for reconstruction of large bone defects, such as hydroxyapatite (HA), collagen, $\beta$-tricalcium phosphate ( $\beta$ TCP), calcium phosphate $[35,36]$. Moreover, an alternative to auto or allografts is titanium mesh cage as a scaffold combined with autologous bone, cancellous bone allograft, and DBM [37,38]. Many of the growth factors appear to have overlapping functions at various stages of bone healing, making it difficult to identify the specific role of a single growth factor or a combination of a few growth factors at each stage. Bone morphogenetic proteins are suggested to act locally both to recruit stem cells and to induce them to differentiate into boneforming cells such as osteoblasts [39]. Thus, scaffold for bone reconstruction should be three dimensional, accelerate osteoinductivity, increase cell migration, and release growth factors [40]. Even though new treatment techniques have been used as alternatives to traditional techniques, the obstreperous conditions, still the same, and traditional techniques must be applied.

\section{Systemic Enhancement of Bone Healing}

Recombinant human parathyroid hormone (PTH) is a new treatment for postmenopausal osteoporosis that can be systemically administered for the primary purpose of increasing bone formation. Many clinical trials showed that PTH administration induces both cancellous and cortical bone healing, enhances bone mass, and increases mechanical bone strength and bone mineral density, with a relatively safety profile [41-43]. Furthermore, systemically administered growth hormone plays an important role in bone metabolism $[44,45]$. Both hormones until now are under investigation to use as bone forming agents in bone defect healing. On the other hand, the use of stimulators of the prostaglandin EP2 and EP4 receptors (anabolic at cortical and cancellous sites), showed good results without adverse effects [46]. Bisphosphonates are a class of drugs that prevent the loss of bone mass, used to treat osteoporosis and similar diseases. It inhibits the digestion of bone by encouraging osteoclasts to undergo apoptosis, or cell death, thereby slowing bone resorption, so it will be useful to enhance bone healing [47].

\section{Scaffolds}

Scaffolds are defined as 3-D porous solid biomaterials designed to promote cell-biomaterial interactions, allow cell proliferation and differentiation, and biodegrade with minimal degree of toxicity in vivo [48]. Scaffolds are biological from human, or synthetic from polymers. 
The first report of tissues regeneration by a scaffold in humans discussed skin regeneration across a gap [49]. Scaffolds strategy for bone defect treatment focused on the mechanical properties (stiffness and compression resistance), nanoscale topography, degradability, and micro/macro porosity, and Nano scale topography. Here, we will present some of the materials used in large bone defects.

\section{Natural Scaffolds}

Natural polymers can be classified as proteins such as silk, collagen, gelatin, fibrinogen, elastin, keratin, actin, and myosin, or as polysaccharides such as cellulose, amylose, dextran, chitin, and glycosaminoglycan [50]. Poly (lactic-co-glycolic acid) (PLAGA) copolymers are among the most commonly used synthetic polymers [51]. For the healing of large bone defects, the mechanical and spacefilling features of the scaffold are at the first place. The combination of degradable polymers and inorganic bioactive particles represents the approach in terms of achievable mechanical and biological performance in hard tissue [52]. Consequently, scaffolds in large bone defects without structural support is a defiance. Therefore, decellularization of harvested tissues have been used as scaffolds, to keep the native architecture [53]. Sponge or foam porous scaffold have been used for bone regrowth, their porous network simulates the extracellular matrix allowing cells to interact effectively with their environment. The collagen consists of over 25 molecular isoforms. The most common form is type I collagen, which is organic component of bone. Sponges have been used in bone healing as a delivery vehicle for bone morphogenetic proteins (BMPs) [54] or as gene delivery platforms [55]. Moreover, fabrication of collagen and hydroxyapatite composites have the potential in mimicking and replacing skeletal bones [56]. Chitosan has been used to make sponges, meshes and scaffold which can be used for bone regeneration [57,58]. Scaffold form, allows cell attachment, for that it has been proposed to be as osteoinductive scaffold [59]. Chitosan have been mixed with other matrix components to improve the mechanical properties of the scaffold, so it can be used for clinical applications [60]. Also, combination of chitosan with other polysaccharides [61], and proteins [62], have been used to produce sponge format. Chitosan microsphere scaffolds have been produced for cartilage and osteochondral regeneration [63]. The chitosan molecule allows the material to be used for drug and gene delivery directly from the scaffold [64,65]. Biocompatible hydrogels are used in bone regeneration, and as carriers for drug delivery [66]. Hydrogel with growth factor can act directly to support the development and differentiation of cells in the newly formed tissues [67]. Hydrogels are often favorable for promoting cell migration, angiogenesis, high water content, and rapid nutrient diffusion [68]. The clinical benefit of hydrogels is that they can be applied without invasive techniques to fill the bone defects. Furthermore, they can be combined with osteoinductive factors and cells to promote healing of critical bone defects [69]. Hydrogels such as fibrin $[70,71]$ and gelatin $[72,73]$ showed hopeful results as transporters for therapeutic factors to promote bone regeneration. Hydrogels are insufficient for large bone healing but they can be as component of titanium cages to stimulate new bone formation.

\section{Synthetic Scaffolds}

During last year's several synthetic materials have been widened for critical sized bone defects healing. Calcium phosphate or calcium carbonate-based scaffolds have shown an effect on the healing of critical bone defects, during the formation process, go through the bone-like mineral layer formed on the surface of these materials [74-77]. $\beta$-tricalcium phosphate and calcium phosphate are the earliest compounds which are used as a scaffold for bone regeneration [78]. $\beta T C P$ have been used since 1920 when it has been injected into the gap of bony defect [79]. Furthermore, a composite scaffold composed of $\beta \mathrm{TCP}$, collagen, and autologous bone fragments fixated with fibrin glue to correct cranial defects, demonstrated that the materials composed of $\beta$ TCP with or without collagen would be important for cranial bone regeneration [80]. Problem with $\beta$ TCP is that less new bone is placed than resorbed $\beta$ TCP [81]. This reason has limited its clinical using. Calcium phosphate ceramics, such as hydroxyapatite (HA), are biocompatible materials because their composition is like the apatite in natural bone [82]. Several shapes of HA as bone substitutes are obtainable such as porous and dense blocks, powder, dense and porous granules [83]. The porous forms allow nutrient transport, cell migration, and vascularization $[84,85]$. Otherwise, porous spherical HA granules can be used for drug delivery systems. Previously, researches concentrated on the release of anti-inflammatory or antibacterial drug from HA, to control the infection at the implanted area [86]. Several drugs have been constructed to enhance bone formation, and the loading of HA with these drugs and agents could be a very effective method for enhancing bone formation at the defect site $[87,88]$. Recent studies suggest that released mineral ions such as calcium, phosphate, magnesium and strontium maybe they are responsible to some extent for the behavior of bone precursor cells $[75,89,90]$. Overtime, HA is ambidextrous to obtain and sustain a drug with stable drug release over time [91,92].

\section{Advanced Scaffold Materials and Drug Delivery}

During the past few years' nanotechnology suggest that ceramics can be good stands for drug delivery and controlled extended release. Drugs have been encapsulated in hollow structures of calcium phosphate and then were triggered by ultrasound [93]. Calcium phosphate scaffolds snob the natural bone structure and provide initial structural integrity for bone cells, and their proliferation and differentiation. Thus, most ceramic Nano scaffolds serve as mechanical support, drug transporter, and promote cell growth. Researchers showed a model of using nanotubular Titania as a drug delivery platform to load antibiotics by co-precipitation of the drug and calcium phosphate crystals on the nanostructures [94]. This delivery system showed a time-delayed release of antibiotics for up to three weeks. Furthermore, another study on scaffolds included a composite of silica and calcium phosphates, showed that this material has a continuous release of gentamicin from the scaffolds for 70 days [95]. Another study has used electro spun scaffold which can be used for treating bone defects and drug delivery. This technique depends on the charging of solutions containing polymers, ceramics or metallic precursors with a high voltage. The charged solution is drawn by electric field from orifice onto collector plate to form desirable structures. The structures can be fabricated to mimic various architectures of biological systems, such as fibrous proteins in a native extracellular matrix or collagen fibrils in bone [96]. One more study, demonstrated new magnetic scaffold for bone regeneration. This study proposed new class of magnetic hydroxyapatites which can be used to develop new magnetic ceramic scaffolds with enhanced regenerative properties for bone regeneration based on hyperthermia [97]. Other common synthetic materials used to form scaffolds for bone healing are polymer materials, such as poly (alpha-hydroxy esters) [98], poly(urethanes) [99], and poly(carbonates) [100]. All of them have been applied within large bone defects, as void filler and as an 
osteoconductive matrix. Synthetic hydrogels can incorporate and deliver controllable dosages of robust molecules, such as growth factors and cell adhesion peptides. Furthermore, self-assembling hydrogels have been designed to nucleate mineral formation, present peptides for cell adhesion $[101,102]$, or present peptides for growth factor binding [103]. Other studies demonstrated that mineral-coated hollow tubes composed of poly( $\varepsilon$-caprolactone) can stimulate bone regeneration in sheep tibia defects [104] and sheep lumbar spine fusion [105]. Moreover, it is remarkable that naturally-derived polymers can also be synthetically modified to create natural/synthetic hybrids that stimulate bone formation, such as alginate hydrogels which can be used to deliver bone-forming stem cells or osteoinductive growth factors [106]. A modern method for creating porous scaffolds composed of micro and nano scale biodegradable fibers by electrospinning is a latest development in this field [107]. Microsphere scaffolds are progressively used as drug delivery systems for antibiotic treatment of infected bone [108]. These scaffolds are a polymer matrix used for drug encapsulation for the release of drugs at a relatively slow rate over a prolonged period [109]. Polymers with low molecular weight are used in developing porous microspheres for the rapid release of the drug, while polymers with high molecular weight for developing microspheres for a slower drug release which can be achieved due to its dense nature [110]. Furthermore, particle aggregation method is proposed to make two layered scaffolds to improve bone and cartilage interface. Also, PLAGA microsphere scaffolds are used as a scaffold for load-bearing bone tissue [111]. The gel microsphere matrix and the sintered microsphere matrix were designed using PLAGA microspheres to create a 3-D porous structure for bone regeneration [112]. Polymer-ceramic microspheres are also used for bone applications [113]. Nano fibers have been used as scaffolds for bone repair and as vehicle for the controlled delivery of drugs [114]. Natural polymers and synthetic polymers inspected to produce nanofibers scaffold for biomedical application such as collagen [115], gelatin [116], chitosan [117], PLGA [118], poly (ethylene-vinyl acetate) (PEVA) [119], and PLLACL-collagen fibers [120]. Drugs, growth factors, and genes can be directly mixed into the polymer solution and electro spun to prepare drug carriers with controlled release properties [121]. It is reported that simvastatin promotes osteoblastic activity and inhibit osteoclastic activity. However, the half-life for simvastatin is 2 hours, so, it is difficult to maintain active simvastatin. To overcome this limitation, researchers proposed controlled drug delivery approaches based on microparticles which could be a promising approach for sustained-localized delivery of simvastatin [122]. Furthermore, the novel PLGA/HA/SIM Nanofibrous scaffold may be beneficial for patients who have bone deficiency soon [123].

\section{Neovascularization}

With microvascular surgical techniques, vascularized bone grafting became a good option to provide restoration of large bone defects. Vascularized bone grafts include the fibula, iliac crest and the ribs. This treatment style requires special skills; however, it is considered as procedure with limitations [124]. The limited clinical success of scaffold strategies may be explained by a lack of vascularization. Studies have demonstrated that new bone formation in porous scaffolds was significantly increased by the insertion of a vascular pedicle in the scaffold $[125,126]$. Therefore, promoting angiogenesis is an important aspect to enhance large bone defects healing. There are various techniques to enhance angiogenesis into the scaffold. One of these procedures is the implantation of a scaffold into a rich arterial supply area such as the abdominal mesentery [127], then waiting for the scaffold to become vascularized, removing the scaffold, and replanting the scaffold into the bone defect. The next procedure is seeding of vasculogenic cells or endothelial cells onto a scaffold. In addition, fusion of VEGF into a scaffold material has been shown to induce angiogenesis and promote bone formation [128], also a combination therapy of VEGF and BMPs seems to have a synergistic effect on bone formation during the first few weeks of treatment of critical size of bone defects [129]. Currently, Jusoh et al. have proposed 3D microvascular networks in a hydroxyapatite-incorporated extracellular matrix for designing a vascularized bone tissue model in a microfluidic device. This study concluded that hydroxyapatite enhanced angiogenic properties such as sprout length, sprouting speed, sprout number, and lumen diameter [130].

\section{Cell Based}

This strategy depends on seeded scaffolds with cells before implantation, or acellular scaffolds that require in vivo recruitment of autologous cells [131]. Studies have been shown that fresh mesenchymal stem cells from the bone marrow can lead to improved bone healing if more than 1,500 colonies forming units of mesenchymal cells are applied per $1 \mathrm{~cm}^{3}$ of defect [132]. Therefore, for large bone defects, exogenous cells may be necessary. Some studies suggested that allogeneic MSCs are hypoimmunogenic relative to other cell types [133]. Adipose-derived mesenchymal stem cells are multipotent cells that can differentiate into numerous cell types including osteogenic cells [134]. Studies demonstrated that osteoinduced ADMSCs successfully repaired the defect when seeded on coral scaffolds, also when seeded on polylactic acid scaffolds $[135,136]$. Finally, chondrocytes may help in healing of critical size defects of the calvarias. Doan et al. demonstrated that chondrocytes, when implanted directly into a critical size cranial defect in mice, heal the defect by 6 weeks' post implantation [137]. Although application of MSCs as cellular material facilitates the construct innovation, there is still some issue with MSC preparation. Furthermore, natural bone is a composite of Nano hydroxyapatite particles with collagen nanofibers which impart the tissue's unique properties [138].

\section{Gene Therapy}

This procedure depends on delivery of protein of interest by a vector to the bone defect. The encoding gene can be obtained from the recipient and implanted at the defect site $[139,140]$. Vectors are important to optimize the transduction of encoding genes. Vectors can be viral or non-viral (polyplexes, DNA plasmids, lipoplexes etc.), but generally vectors still did not achieve the intrinsic efficiency [139-141]. Although, a great number of articles which demonstrated successes in healing of large bone defects, but all have been applied on animal's models, without attentions to toxicology and other matters [142-144]. An update review [140] listed experimental studies conducted to evaluate the in vivo and ex vivo gene transfer, using viral and non-viral and thus establishing parameters of efficiency and safety, major difficulties, advantages and disadvantages of each method. The authors referred to expected future improvements in gene therapy, emphasizing that although promising results have been achieved in animal models, human trials have not yet been reported. 
Page 5 of 8

\section{Conclusion}

Large bone defects do not heal by itself. Despite therapeutic strategies discussed in this review, there is insufficiency of confirmed product which give effective results clinically.

\begin{tabular}{|c|c|}
\hline Modality & Pros and Cons \\
\hline Masquelet & $\begin{array}{l}\text { Clinical technique use non-vascularized autograft. } \\
\text { Needs two stages [18] }\end{array}$ \\
\hline Distraction & $\begin{array}{l}\text { Clinical technique use intramedullary devices. } \\
\text { Needs long time and may associate with } \\
\text { complications }[19,20]\end{array}$ \\
\hline Autografts & $\begin{array}{l}\text { Clinical technique requires an additional surgical } \\
\text { procedure. Do not stimulate immune response, } \\
\text { and can integrate into their new site, but associate } \\
\text { with morbidity }[23-26]\end{array}$ \\
\hline Allografts and Xenografts & $\begin{array}{l}\text { Lack cellular component and osteoinductive } \\
\text { properties [27]. Have lazy incorporation and likely } \\
\text { graft rejection. Freeze drying may modify the } \\
\text { architecture of the grafts }[28,29]\end{array}$ \\
\hline $\begin{array}{l}\text { Natural or synthetic } \\
\text { scaffolds }\end{array}$ & $\begin{array}{l}\text { Even have been used as alternatives to traditional } \\
\text { techniques, the obstreperous conditions, still the } \\
\text { same. Limited clinical success of scaffold } \\
\text { strategies }[60,70,85]\end{array}$ \\
\hline $\begin{array}{l}\text { Advanced scaffold } \\
\text { materials and drug delivery }\end{array}$ & $\begin{array}{l}\text { It is difficult to maintain active drug delivery even } \\
\text { proposed controlled drug delivery based on } \\
\text { microparticles [123] }\end{array}$ \\
\hline Vascularized bone grafting & $\begin{array}{l}\text { Requires special skills; however, it is considered } \\
\text { as procedure with limitations [124] }\end{array}$ \\
\hline Cell based & $\begin{array}{l}\text { Although application of MSCs as cellular material } \\
\text { facilitates the construct innovation, there is still } \\
\text { some issue with MSC preparation. Furthermore, } \\
\text { natural bone is a composite of Nano } \\
\text { hydroxyapatite particles with collagen nanofibers } \\
\text { which impart the tissue's unique properties [138] }\end{array}$ \\
\hline Gene therapy & $\begin{array}{l}\text { Although, demonstrated successes in healing of } \\
\text { large bone defects, but all have been applied on } \\
\text { animal's models, without attentions to toxicology } \\
\text { and other matters [139-141] }\end{array}$ \\
\hline
\end{tabular}

Table 1: Pros and Cons of strategies used to enhance large bone defect healing.

Possibly those strategies have based on inappropriate understanding of bone defects healing. However, autografts still the best therapeutic strategy for large bone defects. The limitations of allografts and xenografts, imposed to look for an ideal composite graft and optimal delivery system for osteoconductive materials, osteogenic cells, and osteoinductive growth factors. Unfortunately, the synthetic and organic biomaterials available to stimulate osteogenesis does not meet the expectations required for bone graft substitute. Local stimulation with growth factors or drugs still needs a proper carrier and a definition of dose and time sequence appropriate for the kinetics of bone healing. Moreover, a small number of clinical trials with inconclusive results do not guarantee growth factors effectiveness in the medical settings. There is still little information available about the cellular basis for MSC mediated bone healing in humans. Finally, knowledge concerning the interaction of nanoparticles within the body are still nominal (Table 1).

\section{References}

1. Schmitz JP, Hollinger JO (1986) The critical size defect as an experimental model for craniomandibulofacial nonunions. Clin Orthop Relat Res 205: 299-308.

2. Chen X, Song F, Jhamb D, Li J, Bottino MC, et al. (2015) The axolotl fibula as a model for the induction of regeneration across large segment defects in long bones of the extremities. PLoS One 10: e0130819.

3. Phillips AM (2005) Overview of the fracture healing cascade. Injury 36 : S5-S7.

4. Bigham AS, Shadkhast M, Bigham Sadegh A, Shafiei Z, Lakzian A, et al. (2011) Evaluation of osteoinduction properties of the demineralized bovine foetal growth plate powder as a new xenogenic biomaterial in rat. Res Vet Sci 91: 306-310.

5. Parizi AM, Oryan A, ShafieiSarvestani Z, Bigham AS (2012) Human platelet rich plasma plus Persian gulf coral effects on experimental bone healing in rabbit model: radiological, histological, macroscopical and biomechanical evaluation. J Mater Sci Mater Med 23: 473-483.

6. Shafiei Z, Bigham AS, Dehghani SN, Nezhad ST (2009) Fresh cortical autograft versus fresh cortical allograft effects on experimental bone healing in rabbits: Radiological, histopathological and biomechanical evaluation. Cell Tissue Bank 10: 19-26.

7. Harth KC, Rosen MJ (2009) Major complications associated with xenograft biologic mesh implantation in abdominal wall reconstruction. Surg Innov 16: 324-329.

8. Levai JP, Bringer O, Descamps S, Boisgard S (2003) Xenograft-related complications after filling valgus open wedge tibial osteotomy defects. Rev Chir Orthop Reparatrice Appar Mot 89: 707-711.

9. Alam S, Ueki K, Nakagawa K, Marukawa K, Hashiba Y, et al. (2009) Statin-induced bone morphogenetic protein (BMP) 2 expression during bone regeneration: An immunohistochemical study. Oral Surg Oral Med Oral Pathol Oral Radiol Endod 107: 22-29.

10. Kheirallah M, Almeshaly H (2016) Simvastatin, dosage and delivery system for supporting bone regeneration, an update review. J Oral Maxillofac Surg Med Path 28: 205-209.

11. Karimi M, Ghasemi A, Zangabad PS, Rahighi R, Basri MM, et al. (2016) Smart micro/nanoparticles in stimulus-responsive drug/gene delivery systems. Chem Soc Rev 45: 1457-1501.

12. Mirjalili F, Soltani M, Chen P (2012) Nanotechnology in drug delivery systems. IJDD 4: 275-288.

13. Fishero BA, Kohli N, Das A, Christophel JJ, Cui Q (2015) Current concepts of bone tissue engineering for craniofacial bone defect repair. Craniomaxillofac Trauma Reconstr 8: 23-30.

14. Gadeau AP, Chaulet H, Daret D, Kockx M, Daniel-Lamaziere JM, et al. (2001) Time course of osteopontin, osteocalcin, and osteonectin accumulation and calcification after acute vessel wall injury. J Histochem Cytochem 49: 79-86.

15. Sikavitsas VI, Temenoff JS, Mikos AG (2001) Biomaterials and bone mechanotransduction. Biomaterials 22: 2581-2593.

16. Nudelman F, Pieterse K, George A, Bomans PHH, Friedrich H, et al. (2010) The role of collagen in bone apatite formation in the presence of hydroxyapatite nucleation inhibitors. Nat Mater 9: 1004-1009.

17. Kheirallah M, Almeshaly H (2016) Bone graft substitutes for bone defect Regeneration. A collective review. Int J Dentistry Oral Sci 03: 247-257.

18. Masquelet AC, Begue T (2010) The concept of induced membrane for reconstruction of long bone defects. Orthop Clin North Am 41: 27-37.

19. Cole JD, Justin D, Kasparis T, DeVlught D, Knobloch C (2001) The intramedullary skeletal kinetic distractor (ISKD): First clinical results of a new intramedullary nail for lengthening of the femur and tibia. Injury 32 : 129-139.

20. Gubin AV, Borzunov DY, Malkowa TA (2013) The Ilizarov paradigm: Thirty years with the Ilizarov method, current concerns and future research. Int Orthop 37: 1533-1539. 
21. Waselau M, Samii VF, Weisbrode SE, Litsky AS, Bertone AL (2007) Effects of a magnesium adhesive cement on bone stability and healing following a metatarsal osteotomy in horses. Am J Vet Res 68: 370-378.

22. Witoon N, Tangvirivapaiboon $\mathrm{T}$ (2014) Clinical and radiological outcomes of segmental spinal fusion in transforaminal lumbar interbody fusion with spinous process tricortical autograft. Asian Spine J 8: 170-176.

23. Pederson WC, Person DW (2007) Long bone reconstruction with vascularized bone grafts. Orthop Clin North Am 38: 23-35.

24. Ahlmann E, Patzakis M, Roidis N, Shepherd L, Holtom P (2002) Comparison of anterior and posterior iliac crest bone graft in terms of harvest-site morbidity and functional outcomes. J Bone Joint Surg Am 84: 716-720.

25. St John TA, Vaccaro AR, Sah AP, Schaefer M, Berta SC, et al. (2003) Physical and monetary costs associated with autogenous bone graft harvesting. Am J Orthop 32: 18-23.

26. Younger EM, Chapman MW (1989) Morbidity at bone graft donor sites. J Orthop Trauma 3: 192-195.

27. Finkemeier CG (2002) Bone-grafting and bone-graft substitutes. J Bone Joint Surg Am 84: 454-464.

28. Bigham AS, Dehghani SN, Shafiei Z, Torabi Nezhad S (2008) Xenogenic demineralized bone matrix and fresh autogenous cortical bone effects on experimental bone healing: radiological, histopathological and biomechanical evaluation. J Orthop Traumatol 9: 73-80.

29. Nandi SK, Roy S, Mukherjee P, Kundu B, De DK, et al. (2010) Orthopaedic applications of bone graft \& graft substitutes: a review. Indian J Med Res 132: 15-30.

30. Gamradt SC, Lieberman JR (2003) Bone graft for revision hip arthroplasty biology and future applications. Clin Orthop 413: 183-194.

31. Badylak SF, Freytes DO, Gilbert TW (2009) Extracellular matrix as a biological scaffold material: Structure and function. Acta Biomater 5: 1-13.

32. Kim KS, Lee JY, Kang YM, Kim ES, Kim GH, et al. (2010) Small intestine submucosa sponge for in vivo support of tissue-engineered bone formation in the presence of rat bone marrow stem cells. Biomaterials 31: 1104-1113.

33. Moore DC, Pedrozo HA, Crisco JJ III, Ehrlich MG (2004) Preformed grafts of porcine small intestine submucosa (SIS) for bridging segmental bone defects. J Biomed Mater Res A 69: 259-266.

34. Khan SN, Fraser JF, Sandhu HS, Cammisa FP, Girardi FP, et al. (2005) Use of osteopromotive growth factors, demineralized bone matrix, and ceramics to enhance spinal fusion. J Am Acad Orthop Surg 13: 129-37.

35. Giannoudis PV, Dinopoulos H, Tsiridis E (2005) Bone substitutes: An update. Injury 36: S20-27.

36. Kim DH, Lee N, Shin DA, Yi S, Kim KN, et al. (2016) Matched comparison of fusion rates between hydroxyapatite demineralized bone matrix and autograft in lumbar interbody fusion. J Korean Neurosurg Soc 59: 363-367.

37. Bullens PH, Bart Schreuder HW, de Waal Malefijt MC, Verdonschot N Buma P (2009) Is an impacted morselized graft in a cage an alternative for reconstructing segmental diaphyseal defects?. Clin Orthop Relat Res 467: 783-791.

38. Ostermann PA, Haase N, Rübberdt A, Wich M, Ekkernkamp A (2002) Management of a long segmental defect at the proximal metadiaphyseal junction of the tibia using a cylindrical titanium mesh cage. J Orthop Trauma 16: 597-601.

39. Guldberg RE (2009) Spatiotemporal delivery strategies for promoting musculoskeletal tissue regeneration. J Bone Miner Res 24: 1507-1511.

40. Correia SI, Pereira H, Siva-Correia J, Van-Dijk CN, Espregueira-Mendes J, et al. (2013) Current concepts: Tissue engineering and regenerative medicine applications in the ankle joint. J R Soc Interfac 11: 20130784.

41. Rubin MR, Bilezikian JP (2005) Parathyroid hormone as an anabolic skeletal therapy. Drugs 65: 2481-2498.

42. Tzioupis CC, Giannoudis PV (2006) The safety and efficacy of parathyroid hormone $(\mathrm{PTH})$ as a biological response modifier for the enhancement of bone regeneration. Curr Drug Saf 1: 189-203.
43. Alkhiary YM, Gerstenfeld LC, Krall E, Westmore M, Sato M, et al. (2005) Enhancement of experimental fracture-healing by systemic administration of recombinant human parathyroid hormone (PTH 1-34). J Bone Joint Surg Am 87: 731-741.

44. Tran GT, Pagkalos J, Tsiridis E, Narvani AA, Heliotis M, et al. (2009) Growth hormone: Does it have a therapeutic role in fracture healing ?. Expert Opin Investig Drugs 18: 887-911.

45. Theyse LF, Oosterlaken-Dijksterhuis MA, van Doorn J, Dhert WJ, Hazewinkel HA (2006) Growth hormone stimulates bone healing in a critical-sized bone defect model. Clin Orthop Relat Res 446: 259-267.

46. Hadjiargyrou M, O'Keefe JR (2014) The convergence of fracture repair and stem cells: Interplay of genes, aging, environmental factors and disease. J Bone Miner Res 29: 2307-2322.

47. Kanis JA, Burlet N, Cooper C, Delmas PD, Reginster JY, et al. (2008) European society for clinical and economic aspects of osteoporosis and osteoarthritis (ESCEO): European guidance for the diagnosis and management of osteoporosis in postmenopausal women. Osteoporos Int 19: $399-428$

48. Langer R, Tirrell DA (2004) Designing materials for biology and medicine. Nature 428: 487-492.

49. Burke JF, Yannas OV, Quinby WC (1981) Successful use of a physiologically acceptable artificial skin in the treatment of extensive burn injury. Ann Surg 194: 413-427.

50. Yannas IV (2004) Classes of materials used in medicine: natural materials, in Biomaterials Science: An introduction to materials in medicine. In: Ratner BD, Hoffman AS, Schoen FJ, Lemons J (Eds.) Elsevier Academic Press pp: 127-136.

51. Ma PX (2004) Scaffolds for tissue fabrication. Materials Today 7: 30-40.

52. Roether JA, Boccaccini AR, Hench LL, Maquet V, Gautier S, Jérôme R (2002) Development and in vitro characterisation of novel bioresorbable and bioactive composite materials based on polylactide foams and bioglass for tissue engineering applications. Biomaterials 23: 3871-3878.

53. Cheng CW, Solorio LD, Alsberg E (2014) Decellularized tissue and cellderived extracellular matrices as scaffolds for orthopaedic tissue engineering. Biotechnol Adv 32: 462-484.

54. Geiger M, Li RH, Friess W (2003) Collagen sponges for bone regeneration with rhBMP-2. Adv Drug Deliv Rev 55: 1613-1629.

55. Tierney EG, Duffy GP, Cryan SA, Curtin CM, O’Brien FJ (2013) Nonviral gene-activated matrices: next generation constructs for bone repair. Organogenesis 9: 22-28.

56. Wahl DA, Czernuszka JT (2006) Collagenhydroxyapatite composites for hard tissue repair. Eur Cell Mater 11: 43-56.

57. Costa-Pinto AR, Reis RL, Neves NM (2011) Scaffolds based bone tissue engineering: the role of chitosan. Tissue Eng Part B Rev 17: 331-347.

58. Heinemann C, Heinemann S, Bernhardt A, Lode A, Worch H, et al. (2010) In vitro osteoclastogenesis on textile chitosan scaffold. Eur Cell Mater 19: 96-106.

59. Di Martino A, Sittinger M, Risbud MV (2005) Chitosan: A versatile biopolymer for orthopaedic tissue engineering. Biomaterials 26: 5983-5990.

60. Venkatesan J, Pallela R, Bhatnagar I, Kim SK (2012) Chitosanamylopectin/hydroxyapatite and chitosan-chondroitin sulphate/ hydroxyapatite composite scaffolds for bone tissue engineering. Int J Biol Macromol 51: 1033-1042.

61. Park H, Choi B, Nguyen J, Fan J, Shafi S, et al. (2013) Anionic carbohydrate-containing chitosan scaffolds for bone regeneration. Carbohydr Polym 97: 587-596.

62. Wang L, Rao RR, Stegemann JP (2013) Delivery of mesenchymal stem cells in chitosan/collagen microbeads for orthopedic tissue repair. Cells Tissues Organs 197: 333-343.

63. Ferrand A, Eap S, Richert L, Lemoine S, Kalaskar D, et al. (2013) Osteogenetic properties of electrospun nanfibtous PCL scaffolds equipped with chitosan-based nanoreservoits of growth factors. Macromol Biosci 14: 45-55. 
64. Cao X, Deng W, Wei Y, Yang Y, Su W, et al. (2012) Incorporating pTGFbeta1/calcium phosphate nanoparticles with fibronectin into 3dimensional collagen/ chitosan scaffolds: Efficient, sustained gene delivery to stem cells for chondrogenic differentiation. Eur Cell Mater 23: 81-93.

65. Goncalves RM, Antunes JC, Barbosa MA (2012) Mesenchymal stem cell recruitment by stromal derived factor-1-delivery systems based on chitosan/poly (gammaglutamic acid) polyelectrolyte complexes. Eur Cell Mater 23: 249-260.

66. Peppas NA, Khare AR (1993) Preparation, structure and diffusional behavior of hydrogels in controlled release. Advanc Drug Deliv Rev 11: 1-35.

67. Tabata Y (2003) Tissue regeneration based on growth factor release. Tissue Engin 9: 5-15.

68. Bryant SJ, Anseth KS (2001) The effects of scaffold thickness on tissue engineered cartilage in photocross linked poly(ethylene oxide) hydrogels. Biomate 22: 619-626.

69. Drury JL, Mooney DJ (2003) Hydrogels for tissue engineering: Scaffold design variables and applications. Biomaterials 24: 4337-4351.

70. Chung YI, Ahn KM, Jeon SH, Lee SY, Lee JH, et al. (2007) Enhanced bone regeneration with BMP-2 loaded functional nanoparticle-hydrogel complex. J Control Release 121: 91-99.

71. Woodruff MA, Rath SN, Susanto E, Haupt LM, Hutmacher DW, et al. (2007) Sustained release and osteogenic potential of heparan sulfatedoped fibrin glue scaffolds within a rat cranial model. J Mol Histol 38: 425-433.

72. Yamamoto M, Takahashi Y, Tabata Y (2003) Controlled release by biodegradable hydrogels enhances the ectopic bone formation of bone morphogenetic protein. Biomaterials 24: 4375-4383.

73. Yamamoto M, Takahashi Y, Tabata Y (2006) Enhanced bone regeneration at a segmental bone defect by controlled release of bone morphogenetic protein-2 from a biodegradable hydrogel. Tissue Eng 12: 1305-1311.

74. Chou YF, Huang W, Dunn JC, Miller TA, Wu BM (2005) The effect of biomimetic apatite structure on osteoblast viability, proliferation, and gene expression. Biomaterials 26: 285-295.

75. Barradas AM, Fernandes HA, Groen N, Chai YC, Schrooten J, et al. (2012) A calcium-induced signaling cascade leading to osteogenic differentiation of human bone marrow-derived mesenchymal stromal cells. Biomaterials 33: 3205-3215.

76. Murphy WL, Hsiong S, Richardson TP, Simmons CA, Mooney DJ (2005) Effects of a bone-like mineral film on phenotype of adult human mesenchymal stem cells in vitro. Biomaterials 26: 303-310.

77. Suarez-Gonzalez D, Barnhart K, Migneco F, Flanagan C, Hollister SJ, et al. (2012) Controllable mineral coatings on PCL scaffolds as carriers for growth factor release. Biomaterials 33: 713-721.

78. Moore WR, Graves SE, Bain GI (2001) Synthetic bone graft substitutes. ANZ J Surg 71: 354-361.

79. Albee FH (1920) Studies in bone growth: triple calcium phosphate as a stimulus to osteogenesis. Ann Surg 71: 32-39.

80. Kishimoto M, Kanemaru S, Yamashita M, Nakamura T, Tamura Y, et al. (2006) Cranial bone regeneration using a composite scaffold of betatricalcium phosphate, collagen, and autologous bone fragments. Laryngoscope 116: 212-216.

81. Hollinger JO, Battistone GC (1986) Biodegradable bone repair materials. Synthetic polymers and ceramics. Clin Orthop Relat Res 207: 290-305.

82. Suchanek W, Yoshimura M (2011) Processing and properties of hydroxyapatite-based biomaterials for use as hard tissue replacement implants. J Mater Res 13: 94-117.

83. Paul W, Sharma CP (1999) Development of porous spherical hydroxyapatite granules: application towards protein delivery. J Mater Sci Mater Med 10: 383-388.

84. Jones AC, Milthorpe B, Averdunk H, Limaye A, Senden TJ, et al. (2004) Analysis of 3D bone ingrowth into polymer scaffolds via micro-computed tomography imaging. Biomater 25: 4947-4954.
85. Karageorgiou V, Kaplan D (2005) Porosity of 3D biomaterial scaffolds and osteogenesis. Biomater 26: 5474-5491.

86. Schlapp M, Friess W (2003) Collagen/PLGA microparticle composites for local controlled delivery of gentamicin. J Pharm Sci 92: 2145-2151.

87. Kim JH, Park YB, Li Z, Shim JS, Moon HS, et al. (2011) Effect of alendronate on healing of extraction sockets and healing around implants. Oral diseases 17: 705-711.

88. Doğan H, Ozcelik B, Senel S (2001) The effect of calcitonin on osseous healing in guinea pig mandible. J endodont 27: 160-163.

89. Shih YR, Hwang Y, Phadke A, Kang H, Hwang NS, et al. (2014) Calcium phosphate-bearing matrices induce osteogenic differentiation of stem cells through adenosine signaling. Proc Natl Acad Sci USA 111: 990-995.

90. Hussain A, Bessho K, Takahashi K, Tabata Y (2012) Magnesium calcium phosphate as a novel component enhances mechanical/physical properties of gelatin scaffold and osteogenic differentiation of bone marrow mesenchymal stem cells. Tissue Eng Part A 18: 768-774.

91. Ginebra M, Traykova T, Planell J (2006) Calcium phosphate cements as bone drug delivery systems: A review. J Control Release 113: 102-110.

92. Kim K, Fisher JP (2007) Nanoparticle technology in bone tissue engineering. J Drug Target 15: 241-252.

93. Cai Y, Pan H, Xu R, Hu Q, Li N, et al. (2007) Ultrasonic controlled morphology transformation of hollow calcium phosphate nanospheres: A smart and biocompatible drug release system. Chem Mater 19: 3081-3083.

94. Yao C, Webster TJ (2009) Prolonged antibiotic delivery from anodized nanotubular titanium using a co-precipitation drug loading method. J Biomed Mater Res Part B Appl Biomater 91: 587-595.

95. Teller M, Gopp U, Neumann HG, Kuhn KD (2007) Release of gentamicin from bone regenerative materials: An in vitro study. J Biomed Mater Res Part B Appl Biomater 81: 23-29.

96. Dai XS, Shivkumar S (2008) Hybrid analogs for the production of porous calcium phosphate scaffolds. Materials Science and Engineering CBiomimetic Supramolecular System 28: 336-340.

97. Tampieri A, D'Alessandro T, Sandri M, Sprio S, Landi E, et al. (2012) Intrinsic magnetism and hyperthermia in bioactive Fe-doped hydroxyapatite. Acta biomater 8: 843-851.

98. Yu NY, Schindeler A, Little DG, Ruys AJ (2010) Biodegradable poly(alpha-hydroxy acid) polymer scaffolds for bone tissue engineering. J Biomed Mater Res B Appl Biomater 93: 285-295.

99. Guelcher SA (2008) Biodegradable polyurethanes: synthesis and applications in regenerative medicine. Tissue Eng Part B Rev 14: 3-17.

100. Luangphakdy V, Walker E, Shinohara K, Pan H, Hefferan T, et al. (2013) Evaluation of osteoconductive scaffolds in the canine femoral multidefect model. Tissue Eng Part A 19: 634-648.

101. Hartgerink JD, Beniash E, Stupp SI (2001) Self-assembly and mineralization of peptide-amphiphile nanofibers. Science 294: 1684-1688.

102. Webber MJ, Tongers J, Renault MA, Roncalli JG, Losordo DW, et al. (2010) Development of bioactive peptide amphiphiles for therapeutic cell delivery. Acta Biomater 6: 3-11.

103. Shah RN, Shah NA, Del Rosario Lim MM, Hsieh C, Nuber G, et al. (2010) Supramolecular design of self-assembling nanofibers for cartilage regeneration. Proc Natl Acad Sci USA 107: 3293-3298.

104. Cipitria A, Reichert JC, Epari DR, Saifzadeh S, Berner A, et al. (2013) Polycaprolactone scaffold and reduced rhBMP-7 dose for the regeneration of critical-sized defects in sheep tibiae. Biomaterials 34: 9960-9968.

105. Yong MR, Saifzadeh S, Askin GN, Labrom RD, Hutmacher DW, et al. (2014) Biological performance of a polycaprolactone-based scaffold plus recombinant human morphogenetic protein-2 (rhBMP-2) in an ovine thoracic interbody fusion model. Eur Spine J 23: 650-657.

106. Lee KY, Mooney DJ (2012) Alginate: properties and biomedical applications. Prog Polym Sci 37: 106-126. 
107. Mirjalili M, Zohoori SJ (2016) Review for application of electrospinning and electrospun nanofibers technology in textile industry. J Nanostruct Chem 6: 207-213.

108. Stephens D, Li L, Robinson D, Chen S, Chang HC, et al. (2000) Investigation of the in vitro release of gentamicin from a polyanhydride matrix. J Control Release 63: 305-317.

109. Berkland C, King M, Cox A, Kim K, Pack DW (2002) Precise control of PLG microsphere size provides enhanced control of drug release rate. J Control Release 82: 137-147.

110. Ravivarapu HB, Burton K, DeLuca PP (2000) Polymer and microsphere blending to alter the release of a peptide from PLGA microspheres. Euro J Pharma Biopharmac 50: 263-270.

111. Borden M, El-Amin SF, Attawia M, Laurencin CT (2003) Structural and human cellular assessment of a novel microsphere-based tissue engineered scaffold for bone repair. Biomater 24: 597-609.

112. Borden M, El-Amin SF, Attawia M, Laurencin CT (2002) The sintered microsphere matrix for bone tissue engineering: In vitro osteoconductivity studies. J Biomed Mater Rese 61: 421-429.

113. Khan YM, Katti DS, Laurencin CT (2004) Novel polymer-synthesized ceramic composite-based system for bone repair: An in vitro evaluation. J Biomed Mater Rese 69: 728-737.

114. Vasita R, Katti DS (2006) Nanofibers and their applications in tissue engineering. Intern J Nanomed 1: 15-30.

115. Matthews JA, Wnek GE, Simpson DG, Bowlin GL (2002) Electrospinning of collagen nanofibers. Biomacromol 3: 232-238.

116. Zhang Y, Ouyang H, Chwee TL, Ramakrishna S, Huang ZM (2005) Electrospinning of gelatin fibers and gelatin/PCL composite fibrous scaffolds. J Biomed Mater Res B 72: 156-165.

117. Geng X, Kwon OH, Jang J (2005) Electrospinning of chitosan dissolved in concentrated acetic acid solution. Biomater 26: 5427-5432.

118. Uematsu K, Hattori K, Ishimoto Y, Yamauchi J, Habata T, et al. (2005) Cartilage regeneration using mesenchymal stem cells and a threedimensional poly-lactic-glycolic acid (PLGA) scaffold. Biomater 26: 4273-4279.

119. Kenawy ER, Bowlin GL, Mansfield K, Layman J, Simpson DG, et al (2002) Release of tetracycline hydrochloride from electrospun poly(ethylene-co-vinyl acetate), poly(lactic acid), and a blend. J Control Release 81: 57-64.

120. Su Y, Su Q, Liu W, Lim M, Venugopal JR, et al. (2012) Controlled release of bone morphogenetic protein 2 and dexamethasone loaded in core-shell PLLACL-collagen fibers for use in bone tissue engineering. Acta Biomater 8: 763-771.

121. Verreck G, Chun I, Rosenblatt J, Peeters J, Dijck AV, et al. (2003) Incorporation of drugs in an amorphous state into electrospun nanofibers composed of a water insoluble, nonbiodegradable polymer. J Control Release 92: 349-360.

122. Nandagiri VK, Muttu C, Daly J, Ramtoola Z, Ciardelli G, et al. (2012) Preparation and characterization of simvastatin loaded PLGA microparticles for tissue engineering applications. Current Res Pharmac Sci 02: 81-90.

123. Jiang L, Sun H, Yuan A, Zhang K, Li D, et al. (2013) Enhancement of osteoinduction by continual simvastatin release from PLGA-HAsimvastatin nano-fibrous scaffold. J Biomed Nanotechnol 9: 1921-1928.

124. Giannoudis PV, Calori GM, Beguec T, Schmidmaier G (2013) Bone regeneration strategies: Current trends but what the future holds? Injury 44: S1-S2.

125. Akita S, Tamai N, Myoui A, Nishikawa M, Kaito T, et al. (2004) Capillary vessel network integration by inserting a vascular pedicle enhances bone formation in tissue-engineered bone using interconnected porous hydroxyapatite ceramics. Tissue Eng 10: 789-795.

126. Kim WS, Kim HK (2005) Tissue engineered vascularized bone formation using in vivo implanted osteoblastpolyglycolic acid scaffold. J Korean Med Sci 20: 479-482

127. Warren SM, Greenwald JA, Nacamuli RP, Fong KD, Song HJ, et al. (2003) Regional dura mater differentially regulates osteoblast gene expression. J Craniofac Surg 14: 363-370.

128. Kleinheinz J, Stratmann U, Joos U, Wiesmann HP (2005) VEGF activated angiogenesis during bone regeneration. J Oral Maxillofac Surg 63: 1310-1316.

129. Patel ZS, Young S, Tabata Y, Jansen JA, Wong ME, et al. (2008) Dual delivery of an angiogenic and an osteogenic growth factor for bone regeneration in a critical size defect model. Bone 43: 931-940.

130. Jusoh N, Oh S, Kim S, Kim J, LI Jeon N (2015) Microfluidic vascularized bone tissue model with hydroxyapatite-incorporated extracellular matrix. Lab Chip 15: 3984-3988.

131. Yoon E, Dhar S, Chun DE, Gharibjanian NA, Evans GR (2007) In vivo osteogenic potential of human adipose-derived stem cells/poly lactide-coglycolic acid constructs for bone regeneration in a rat critical-sized calvarial defect model. Tissue Eng 13: 619-627.

132. Hernigou P, Poignard A, Beaujean F, Rouard H (2005) Percutaneous autologous bone-marrow grafting for nonunions. Influence of the number and concentration of progenitor cells. J Bone Joint Surg Am 87: 1430-1437.

133. Abumaree M, Al Jumah M, Pace RA, Kalionis B (2012) Immunosuppressive properties of mesenchymal stem cells. Stem Cell Rev 8: 375-392.

134. Cui L, Liu B, Liu G, Zhang W, Cen L, et al. (2007) Repair of cranial bone defects with adipose derived stem cells and coral scaffold in a canine model. Biomater 28: 5477-5486.

135. Im GI (2013) Adipose stem cells and skeletal repair. Histol Histopathol 28: 557-564.

136. Jeon O, Rhie JW, Kwon IK, Kim JH, Kim BS, et al. (2008) In vivo bone formation following transplantation of human adipose-derived stromal cells that are not differentiated osteogenically. Tissue Eng Part A 14: 1285-1294.

137. Doan L, Kelley C, Luong H, English J, Gomez H, et al. (2010) Engineered cartilage heals skull defects. Am J Orthod Dentofacial Orthop 137: 162.e1-162.e9.

138. Tollemar V, Collier ZJ, Mohammed MK, Lee MJ, Ameer GA, et al. (2016) Stem cells, growth factors and scaffolds in craniofacial regenerative medicine. Genes \& Diseases 3: 56-71.

139. Devescovi V, Leonardi E, Ciapetti G, Cenni E (2008) Growth factors in bone repair. Chir Organi Mov 92: 161-168.

140. Fischer J, Kolk A, Wolfart St, Pautke C, Warnke PH, et al. (2011) Future of local bone regeneration protein versus gene therapy. J Craniomaxillofac Surg 39: 54-64.

141. Lattanzi W, Parrilla C, Fetoni A, Logroscino G, Straface G, et al. (2008) Ex vivo-transduced autologous skin fibroblasts expressing human Lim mineralization protein-3 efficiently form new bone in animal models. Gene Ther 15: 1330-1343.

142. Evans CH (2012) Gene delivery to bone. Adv Drug Deliv Rev 64: 1331-1340.

143. Evans CH (2010) Gene therapy for bone healing. Expert Rev Mol Med 12: e18.

144. Pensak MJ, Lieberman JR (2013) Gene therapy for bone regeneration. Curr Pharm 19: 3466-3473. 